\title{
三島工場の廃熱回収事例
}

大王製紙株式会社 三島工場 エネルギー企画部＼cjkstart藤＼cjkstart田＼cjkstart卓

\section{Case Studies of Collecting Our Waste-Heat at Mishima Mill, Daio Paper Corporation}

Taku Fujita

Mishima Mill, Daio Paper Corporation

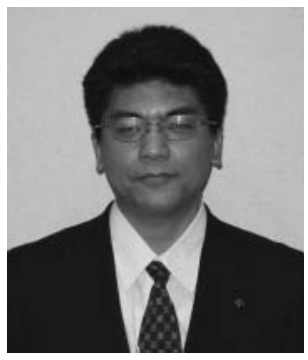

The power generating facility at Misihima Mill has a $531 \mathrm{MW}$ standard output and consists of 18 boilers and 14 turbines. It supplies all the electricity used by the facility and its surplus electricity output is sold to the market.

After the oil crises of the 1970's, Daio Paper shifted from a dependence on petroleum towards coal. Since 1985 we have also attempted to increase energy production efficiency in the power plant by raising the pressure and the temperature in the boilers and installing new turbines. Additionally increased our production of recycled pulp in the production process because it requires less energy than wood chip processing. In 2005, we accomplished a $17 \%$ reduction in fossil fuel energy consumption based on tonnage of output compared to 1990.

We are trying to accomplish a $23 \%$ reduction by 2010 compared with 1990 levels in fossil fuel energy consumption based on tonnage of output, a $20 \%$ reduction in carbon dioxide consumption.

Case studies of our energy curtailment efforts at Mishima Mill are discussed in the following section.

分類： $\mathrm{U}_{1}$ 用水・熱・原動機一般, $\mathrm{U}_{2}$ 省エネルギー

\section{1.はじめに}

三島工場の発電設備（定格出力 $531 \mathrm{MW）は,} \mathrm{ボイラー}$ 18 缶とタービン 14 基で構成され, 工場の使用電力を自家 発電で賄うとともに余剩電力を販売している。

当社は,オイルショック以降重油から石炭への燃料転換 を進めてきた。また，1985 年以降ボイラーの高温高圧化 とタービンの新設により発電設備の高効率化を図るととも に，エネルギー原単位の低い古紙パルプの増産に取組んだ。 その結果, 当社の 2005 年度の化石エネルギー原単位は 1990 年度比で $17 \%$ 削減した。

当社は更なる省エネルギー活動を推進することで，2010 年度までに 1990 年度比で化石エネルギー原単位を $23 \%$ 削 減，二酸化炭素排出原単位を $20 \%$ 削減に取組んでいる。 以下に三島工場廃熱回収の省エネルギー事例を紹介する。

\section{2. 三島工場の概要}

表 1 に三島工場の概要を示す。

\section{3. 廃熱回収事例}

\section{1 廃熱温水の熱回収について}

冬季は水温の低下に伴い，温水製造及び白水加温用等蒸 気使用量が増加し, 蒸気原単位は夏季に比べ悪化していた。 一方バキュームエバポレーター等で発生する温水の内, 一部は熱回収しているが 大半は排水処理設備に送られ熱 損失となっていた。また，発電タービン復水器で熱交換し た温水はクーリングタワーで冷却し，大きな熱損失となっ ていた。

工場内で発生するこれら廃熱温水の熱回収に取組み，プ ロセスに供給する 工業用水温度を年間を通じて一定に維 持する事により，蒸気原単位の改善を図った事例を紹介す る。 
表 1 三島工場概要

\begin{tabular}{|c|c|c|c|c|}
\hline 工場敷地面積 & \multicolumn{4}{|l|}{$1,669,000 \mathrm{~m}^{2}$} \\
\hline 従業員数 & \multicolumn{2}{|l|}{1,850 名 } & & \\
\hline 生産量 & $\begin{array}{ll}\text { 紙・板紙 } & 200 \\
\text { パルプ } & 200\end{array}$ & $\begin{array}{l}\text { V/年 } \\
\text { V/年 }\end{array}$ & & \\
\hline パルプ設備 & $\begin{array}{lr}\text { クラフトパルプ } & 3,2 \\
\mathrm{TMP} & 3 \\
\mathrm{PGW} & 3,6 \\
\mathrm{DIP} & 2,6\end{array}$ & $\begin{array}{l}\text { ン } / \text { 年 } \\
\text { ン } / \text { 年 } \\
\text { ン } / \text { 年 } \\
\text { ン } / \text { 年 }\end{array}$ & & \\
\hline 抄紙・コート紙設備 & $\begin{array}{l}\text { 抄紙機 } \\
\text { コーターマシン }\end{array}$ & & & \\
\hline 動力設備 & $\begin{array}{l}\text { バイオマスボイラー } \\
\text { 石炭ボイラー } \\
\text { 回収ボイラー } \\
\text { スラッジボイラー } \\
\text { 重油ボイラー } \\
\text { (重油ボイラーは定! } \\
\text { 蒸気タービン }\end{array}$ & $\begin{array}{l}1 \text { 缶 } \\
3 \text { 缶 } \\
5 \text { 缶 } \\
3 \text { 缶 } \\
6 \text { 缶 } \\
\text { 止) } \\
14 \text { 基 }\end{array}$ & $\begin{array}{c}\text { 蒸気発生量 } \\
\text { " } \\
" \\
" \\
" \\
\text { 発電量 }\end{array}$ & $\begin{array}{l}100 \text { トン/時 } \\
1,180 \text { トン/時 } \\
880 \text { トン/時 } \\
220 \text { トン/時 } \\
1,205 \text { トン/時 } \\
\\
531 \mathrm{MW}\end{array}$ \\
\hline
\end{tabular}

\section{2 工業用水温度と蒸気原単位について}

工業用水の温度に連動するかたちで，図 1 の通り蒸気原 単位は変動していた。

\section{3 廃熱温水回収に伴う蒸気原単位の改善状況}

工場で発生する廃熱温水を工業用水池に回収し水温を上 げると共に，各プロセスに送る工業用水に廃熱温水を吹込 み, 水温を上げる等の廃熱回収対策を行って加温用蒸気削 減の取組みを行った結果，プロセス送り工業用水の温度は 年間を通じて安定した。その結果，工業用水池の冷水を直 接プロセス側に 供給することはなくなり，図 2 の通り蒸 気原単位は $12 \%$ 改善された。

\section{4 省エネルギー効果}

廃熱温水回収による省エネルギーに取組んだ結果，マシ ンでの温水製造及び白水加温用蒸気の削減等により重油換 算で $62,300 \mathrm{~kL} /$ 年の省エネルギーとなった。 その結果，二酸化炭素排出量を $186,000 \mathrm{~T} /$ 年削減した。

\section{5 実施した主な廃熱回収の内容}

図 3 に工業用水及び廃熱回収フローを示す。

\subsection{1 蒸気タービン復水器の廃熱回収}

蒸気タービン復水器で熱交換した温水をプロセス送り工 業用水に吹込むことにより，各プロセスでの温水製造用お よび白水加温用蒸気使用量の削減を行った。その結果, 9.4

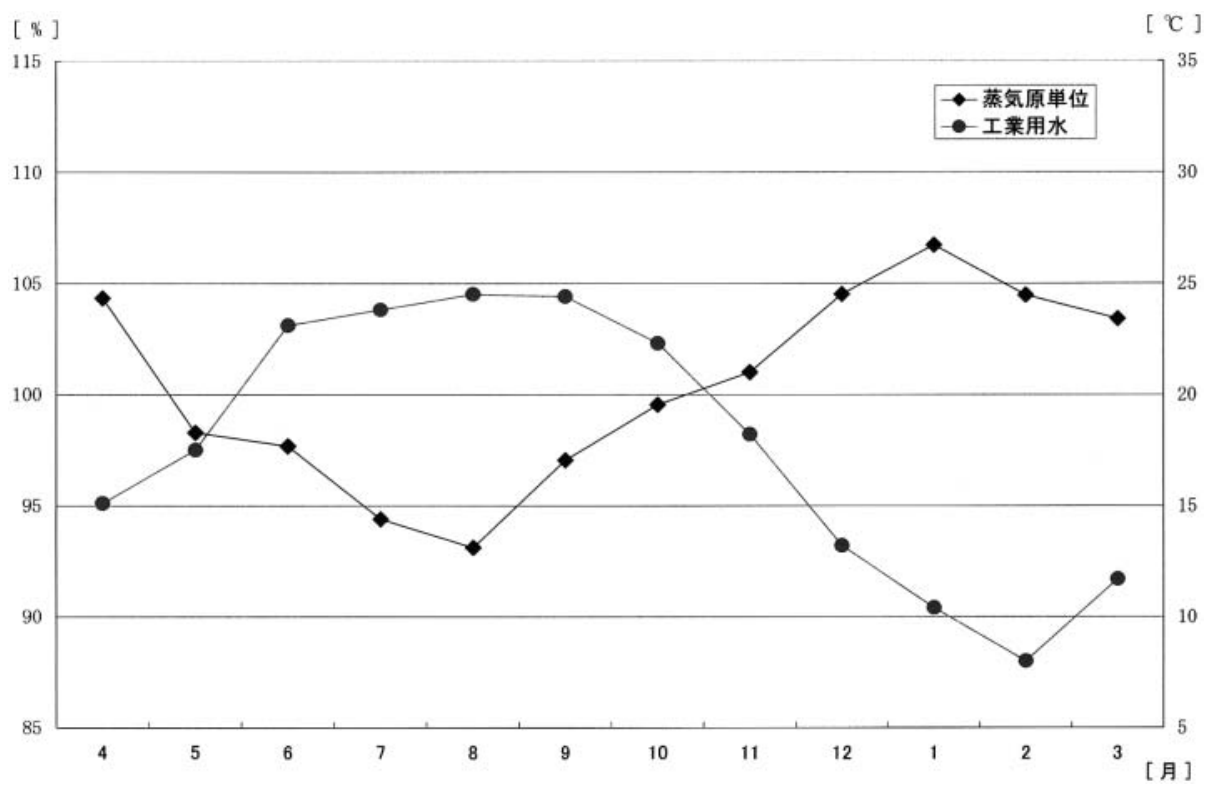

図 1 改善前の工業用水温度及び蒸気原単位推移 


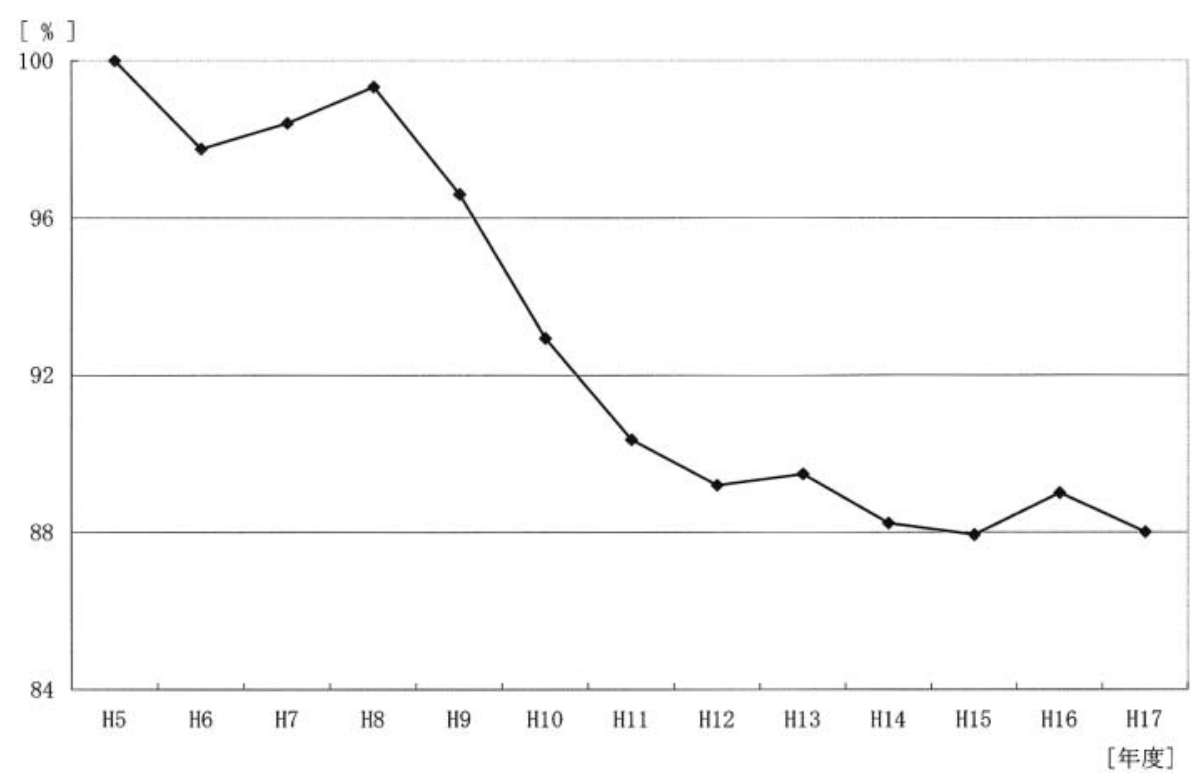

図 2 蒸気原単位推移

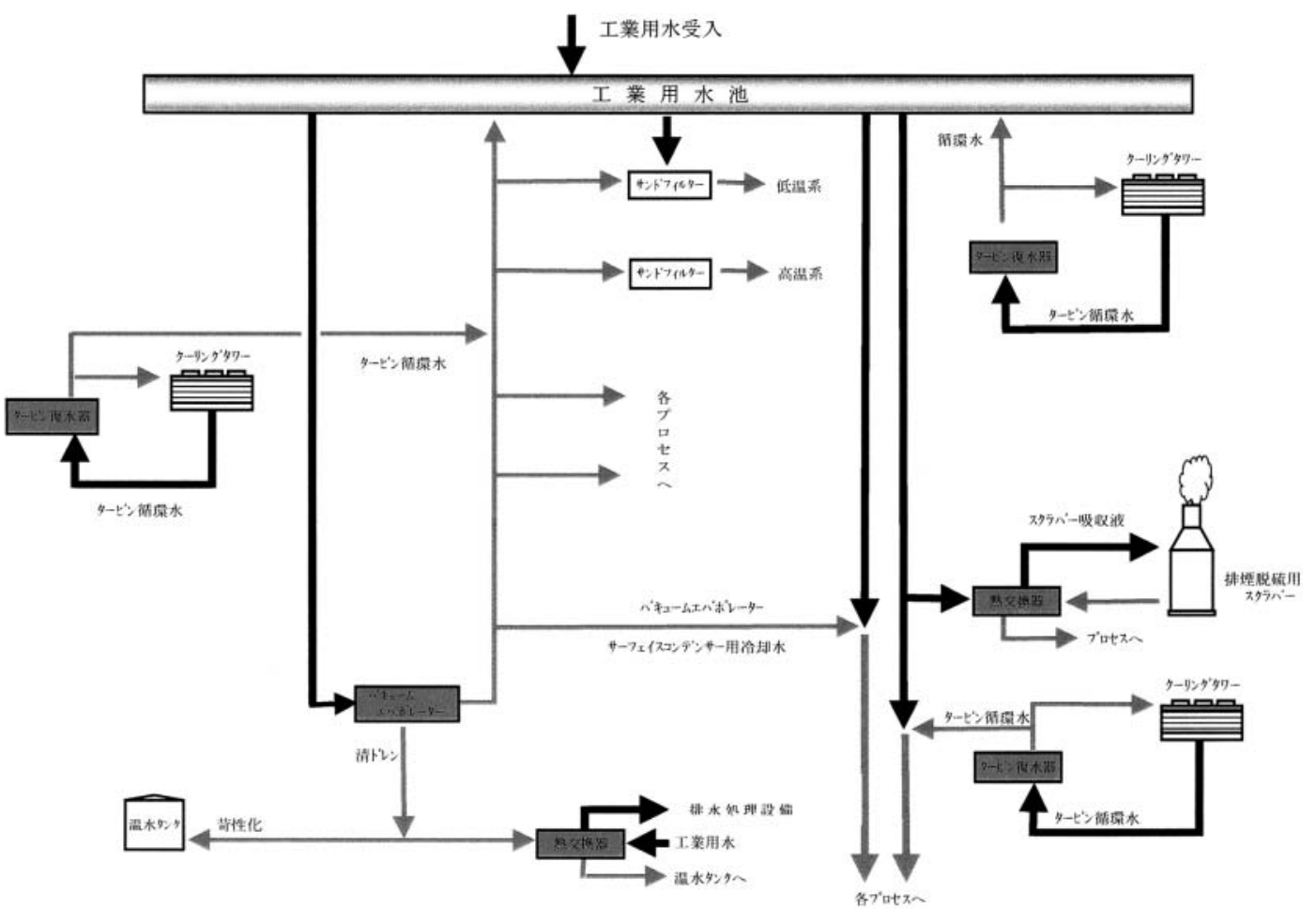

図 3 工業用水及び廃熱回収フロー

$\mathrm{t} / \mathrm{h}$ の蒸気使用量を削減した。

\subsection{2 バキュームエバポレーター温水の廃熱回収}

バキュームエバポレーターで発生する温水を，プロセス 送り工業用水に吹込むことにより，各プロセスでの温水製 造用および白水加温用蒸気使用量の削減を行った。その結 果, $1.9 \mathrm{t} / \mathrm{h}$ の蒸気使用量を削減した。

\section{5 .3 蒸気タービン復水器からの廃熱回収一1}

プロセス側で蒸気を使い温水製造を行っている温水タン クへの補給水を, 温度の低い工業用水から蒸気タービン復 水器で発生する温水に置換えることにより，温水製造用蒸
気の使用量を削減した。その結果， $5.2 \mathrm{t} / \mathrm{h}$ の蒸気使用量 を削減した。

\subsection{4 蒸気タービン復水器からの廃熱回収一2}

蒸気タービン復水器で発生する温水を, 工業用水池に取 り込み循環させることにより，工業用水池の水温を上げプ ロセスでの加温用蒸気の削減を図ると共に，クーリングタ ワー用ブロワー停止による省エネルギーを行った。その結 果，1.6 t/h の蒸気使用量を削減すると共に $50 \mathrm{kw}$ の電力 使用量を削減した。 
3.5 .5 バキュームエバポレーターでの発生温水の廃熱 回収

バキュームエバポレーターで発生する温水は, 夏季は余 剰となっていた。余剒となった温水は従来工業用水池に返 送されていたが, 温水の必要箇所に直接回収することによ り, 加温用蒸気の削減を行った。その結果, $1.5 \mathrm{t} / \mathrm{h}$ の蒸 気使用量を削減した。

\subsection{6 清ドレンの廃熱回収}

バキュームエバポレーターで発生する清ドレンの廃熱回 収を行う為, 熱交換器を設置し清ドレンとプロセス用工業 用水を熱交換させ加温用蒸気の削減を行った。その結果 $2.0 \mathrm{t} / \mathrm{h}$ の温水製造用蒸気使用量を削減した。

\section{5 .7 廃熱回収の系統分け}

プロセス送り工業用水の温度を，廃熱回収温水量を調節
することで高温系と低温系に別け，温水タンクの補給水等 蒸気削減効果の高い所には高温系の温水を, 蒸気削減効果 の低い所には低温水系の温水を送り分けることにより, 廃 熱回収効果を高めた。

4. おわりに

廃熱温水の熱回収を段階的に行った結果，プロセス送り 工業用水の温度は年間を通じて $25^{\circ} \mathrm{C}$ に維持することがで きるようになった。

しかし, 厳寒期は蒸気タービン復水器で熱交換する温水 温度の低下に伴い，プロセスに供給する廃熱温水が未だ不 足している状況にある。このことから, 不足する廃熱温水 を確保する為, 今後新たな廃熱回収を行い蒸気原単位の更 なる削減を継続して行う計画である。 